\title{
Towards a Theology of HIV/AIDS
}

A van Wyngaard ${ }^{1}$

(Swaziland Reformed Church)

\section{ABSTRACT}

\section{Towards a Theology of HIV/AIDS}

In a world which is slowly but surely being devastated by the HIV/AIDS pandemic, the church needs to get involved in the fight against this disease. In many places the church has conveniently denied that HIV/AIDS has anything to do with them. In this paper the author argues for the necessity of thinking theologically about the reality of HIV/AIDS, indicating that HIV/AIDS is not merely a matter of "sinners" becoming infected with a virus, but that certain circumstances are conducive towards the spreading of HIV/AIDS which need to be addressed if an impact is to be made on the spreading of the virus. Although many non-religious organisations are fighting this disease, the church is in an ideal situation to assist these bodies as it is already grounded within communities and already have integrity amongst a large part of the population. However, to achieve this goal the churches must be transformed in the face of the HIV/AIDS crisis, in order that they themselves may become a force for transformation - bringing healing, hope, and accompaniment to all infected with and affected by HIV/AIDS.

\section{INTRODUCTION}

We could not have designed a more frightening disease if we had tried. If we could play at being Satan for the day, charged with the task of designating an epidemic to undermine both the developed and underdeveloped countries of the world at the end of the twentieth century, then the blueprint for the design would incorporate many of the features of AIDS (Connor \& Kingman, quoted in Saayman \& Kriel 1991:154).

It has been said that one cannot speak about Africa today without also mentioning HIV/AIDS. Sadly, this is becoming true for a much larger part of our planet than earlier recognised, including countries

1 This paper was presented to the General Assembly of the Reformed Ecumenical Council held in Utrecht in the Netherlands, from 12 - 25 July 2005. Dr van Wyngaard is a post-graduate student in the Department of Religious Studies and Missiology, University of Pretoria. 
like Asia and Eastern Europe. But there is not a single country in the world, not even highly developed countries like Australia, Europe and North America, which is not being affected by HIV/AIDS. I am sure that we are all aware of the extent of this problem. I am reluctant to mention statistics, because HIV/AIDS statistics seem to fall into the same category as computer technology - what is current today is outdated tomorrow.

At the risk that this paper may become obsolete shortly, it is however important to mention a few statistics to understand the problem with which we are faced. According to UNAIDS, (1998:6) just over 30 million people were HIV-positive and 2.3 million people had died of HIV/AIDS related diseases during 1997. By comparison, in 2004, seven years later, close to 40 million people were living with the $\mathrm{HI}$ virus and more than 3 million people had died because of HIV/AIDS that year. This means roughly a 30\% increase in infections and deaths over a period of seven years, and there is very little indication that things will improve within the near future.

While the effects of this disease may not be as noticeable in Western countries, the same cannot be said for most countries in sub-Saharan Africa and increasingly for many other countries in the world. I come from Swaziland, the country with the highest HIV infection rate in the world. This is a country which, if the population growth had been normal, should by now have had approximately 1.5 million people. Although the exact population of Swaziland is uncertain at present, the country's prime minister, in a recent speech, referred to the 930,000 people of Swaziland. Other sources estimate the figure to be between 1.1 and 1.2 million - still 300 - 400 thousand less than it would have been without HIV/AIDS. Whatever the exact figures may be, the fact remains that the world is faced by a catastrophe which we as the church of Jesus Christ, can no longer afford to ignore. During a global ecumenical consultation which took place in Nairobi in November 2001, representatives from different denominations came to the shocking conclusion that the church is also guilty of contributing towards the HIV/AIDS pandemic by not responding appropriately to the problems of the day:

The churches have strengths, they have credibility, and they are grounded in communities. This offers them the opportunity to make 
a real difference in combating HIV/AIDS. To respond to this challenge, the churches must be transformed in the face of the HIV/AIDS crisis, in order that they may become a force for transformation - bringing healing, hope, and accompaniment to all affected by HIV/AIDS (World Council of Churches 2001:3).

\section{NEED FOR A THEOLOGY OF HIV/AIDS}

I started off by saying that we cannot speak of Africa without speaking about HIV/AIDS. I want to go one step further and say that we can no longer speak about the church without speaking about HIV/AIDS. This then forms the motivation for the theme of this paper: Towards a Theology of HIV/AIDS. Why a theology of HIV/AIDS? Is it justified to formulate a theology for every crisis with which the world is faced? Obviously not. However, at times a crisis develops which has the potential for such devastating consequences throughout the world, that it becomes necessary for the church to respond to that crisis, not only practically, but also theologically. Throughout history there have been times when the church has had to respond in a special way to a particular crisis. Before and during the Second World War theologians such as Karl Barth and Dietrich Bonhoeffer played major roles in influencing the church to take a theological stand against the National Socialism of Germany. In South Africa it was also experienced when the church formulated its objections against the ideology of Apartheid through various theological documents, of which the Kairos Document was probably the most prominent. In fact, Dr McDonagh specifically describes these times as Kairos moments - "the time of God's special presence and summons" with a consequential theological response to this particular call from God (1994:1). The same is implied in a report on HIV/AIDS by the Dutch Reformed Church in South Africa (Diensgroep Diensgetuienis 2004:25). I believe the church has no other option than to respond theologically to this kairos moment in our history. As Maluleke (s.a.) puts is:

Failure to probe the theological significance of this moment will be not only be a missed opportunity but also irresponsible. Just as the entire Christian world has been and continues to be mobilized in programmes meant to combat racism, sexism, economic exploitation and cultural arrogance, we now need theologies that will help us deal with the challenge of HIV/AIDS. 
While busy with the research for this paper, it was interesting for me to note that within Roman Catholic Circles the necessity of a Theology of HIV/AIDS had been recognised long before most Protestant churches deemed it necessary to think theologically about this crisis. McDonagh's ${ }^{2}$ appeal for a Theology of HIV/AIDS, came as early as 1994. In most Reformed theological periodicals that I looked at, however, articles about HIV/AIDS are virtually nonexistent. As far as I could determine, only one book has been published in South Africa which specifically focussed on the Theology of HIV/AIDS, namely a book written by Willem Saayman and Jacques Kriel, with the title: AIDS: The Leprosy of our time? Paula Clifford says: "A theology formulated today without reference to HIV/AIDS is as outdated and potentially irrelevant as one that in earlier centuries reflected the world-view of slave traders or an imperialist elite" (2004:4). In this regard, special mention needs to be made about the attempts made by the REC in general and its general secretary, Dr Richard van Houten in particular, over the past few years to devote at least one article in the REC Focus annually to the problem of HIV/AIDS while in 2002 an entire edition of this publication was directed towards the topic. Although the Dutch Reformed Church in South Africa has committed itself through a synodical decision to effective participation in the battle against HIV/AIDS (Algemene Kommissie Vir Die Diens Van Barmhartigheid 2002:534-535; Diensgroep Diensgetuienis 2004:24-32) and many other churches have done the same, a well-formulated Theology on HIV/AIDS still seems to be lacking within Reformed circles.

\subsection{Relationship between HIV/AIDS and sin}

McDonagh (1994:3) argues that HIV/AIDS raises no new questions about God. However, it raises old questions in a new form on the relation between human suffering and God's presence. Some people consider HIV/AIDS simply as God's punishment for mankind's sin (Van der Walt 2004:6-8; Douma 1987:31-34; Clifford 2004:3). From

2 Rev Dr Enda McDonagh, is a member of the Caritas Internationalis Task Force on HIV and AIDS and Emeritus Professor of Moral Theology, Maynooth College, University of Ireland. Caritas Internationalis is a confederation of Catholic, nationally-based social assistance and development agencies active in 194 countries and territories of the world. This organization has prioritized action in response to HIV/AIDS since 1987 (Vitillo, s.a.). 
Biblical times the question has been raised whether sickness or suffering could somehow be the direct result of sin. This forms the central theme of the story of Job. During the medieval ere, the Black Death killed approximately 80 million people in Europe between 1346 and 1350, and many people believed that this was also the judgement of God because of mankind's sin. According to history, in an attempt to soften God's heart, King Philip of France gave the order that all slanderers and atheists' lips had to be cut off. Officers of the French army were forbidden to gamble or swear and couples who were living together without being married were ordered to get married immediately - leading to numerous instantaneous marriages. All this was an attempt to calm God's anger (Louw 1988:66).

While most responsible theologians would probably not support such an extreme viewpoint which links HIV/AIDS directly to God's judgement, many people are nevertheless fairly comfortable saying that those who are HIV-positive due to an immoral life, such as homosexuals or those who use intravenous drugs, are only getting their just reward for their lifestyle. According to this viewpoint, which may be more common than we care to admit, HIV/AIDS is no longer seen as God's judgement over mankind in general, but it is seen more specifically as God's judgement over individuals who are living a sinful life.

However, increasingly people are realising that even such a viewpoint is much too simplistic. To raise but two objections against such a viewpoint: Many people living immorally or using drugs are not HIV-positive. Why does God not punish them as well, if His intention is to punish all sinners? This would also imply that female homosexuals are less sinful than their male counterparts, as HIV/AIDS is virtually non-existent among lesbians (McCloughry \& Bebawi, quoted in Van Wyk 1990:8).

If it seems that certain sinners are being pardoned, then the opposite is also true. As in the case with Job, many people who are HIV-positive are also suffering innocently. Madipoane Masenya (2001:186-199) wrote a moving story, based on the biblical account of Job and his friends, about a devout Christian woman with the name of Mmalehu who was infected with the HI virus, not through her own immoral life, but through the infidelity of her husband. Through this story Masenya raises the important theological question on the relationship between HIV/AIDS and sin. 
In contrast with those who claim that HIV/AIDS is God's judgement over sin, the more modern trend seems to be to consider all people who are HIV-positive merely as victims of a disease. In a Theology of HIV/AIDS it would be essential to formulate a Biblical view on the relation between HIV/AIDS and sin, obviously not with the intention of stigmatising those who are HIV-positive, a topic which also needs to be discussed in a Theology of HIV/AIDS, but to better understand the tragic effects that sin has had upon God's creation throughout history - HIV/AIDS being one of the most vivid examples of the consequences of the power of sin today (Reid 1987:31-33; Rubingh 2002:46).

\subsection{Speaking out about sex and sexuality}

While speaking about the effects of sin in the world, the church will also have to acknowledge its failure to promote a life which may be lived to the full, often because of its neglect to speak out about issues which need to be discussed. During the Global Consultation on AIDS (World Council of Churches 2001:2) it was said: "Our difficulty in addressing issues of sex and sexuality has often made it painful for us to engage, in any honest and realistic way, with issues of sex education and HIV prevention". For years the church has warned against the evil of sexual immorality, of pre- and extramarital sexual relations, but perhaps too little has been done to enable Christians to celebrate the gift of human sexuality that God has given to us. All would agree that the main method in which the $\mathrm{HI}$ virus is transmitted from one person to another is through sexual contact. Yet, surprisingly, sexuality has received very little attention in theological discussions on the pandemic, apart from warning against high-risk behaviour. In another document of the World Council of Churches (2004:33) it says: “...if sound moral decisions are required of people, an environment conducive to making such decisions is necessary, an environment in which openness to honest sharing of experiences and concerns is promoted and the integrity of people and their relationships is affirmed. Apart from such an environment, the vulnerability of marginalized groups to high-risk behaviour is greatly increased".

\subsection{Where is God in HIV/AIDS?}

Another aspect which needs to be included in a Theology of HIV/AIDS is how to address the chaos and disorder which seem to have been caused by the HIV/AIDS pandemic (Clifford 2004:4). In a 
world where we should be experiencing victory over plagues, we have been confronted by a new reality - a virus which medical science has been unable to conquer. In the words of Tinyiko Maluleke (s.a): "The AIDS pandemic recreates for us the frightening world of the earlier church where we do not control the elements and are in a place between creation and redemption..." We are faced with a totally abnormal situation, where "the processes that we associate with giving life are bringing death" (David Atkinson, quoted in Clifford 2004:4). Within this abnormal situation faced by both those infected with HIV as well as those taking care of them, the church needs to ask and answer certain fundamental theological questions, such as: Where is God in HIV/AIDS? or rephrased in the words of Clifford (2004:4): "What is the nature of God as he is revealed through this epidemic?” What does this disease tell us about God's creation?

\subsection{A Message of Hope!}

However, as we reflect on the effect that HIV/AIDS has on God's creation, the Bible also has another message, a message of hope and redemption (Rubingh 2002:47-48). One has only to spend a few minutes in a hospital in any Third World country to realise the need for a message of redemption and hope. Entering such a hospital, one is immediately surrounded by a feeling of total hopelessness. The smell of death is evident as one moves from ward to ward, confronted, more often than not, by people more resembling skeletons than human beings. As family members care for their loved ones in the wards, forced to do so because of the lack of sufficient numbers of nurses in most hospitals, the acceptance of the inevitable is written on their faces. Their loved one, be it a husband or wife, son or daughter, mother or father, will probably not leave the hospital alive, but even if the family members are forced to take the patient home in order to vacate the bed so as to make room for another patient also on the verge of dying, then it will only be in order that the patient can die at home. This is the reality which is facing millions of people today.

Within this seemingly hopeless situation, the church has a message of hope and redemption. It was the great preacher, Charles Spurgeon, who said that whoever is able to bring a message of comfort and hope through their sermons will never lack a congregation. There has hardly been a time when a message of comfort and hope was more needed, than in our days. Regardless 
how people acquired the HI virus, all need to hear the comforting message of God's grace through which they can have hope, not only for the future life after death, but also for our life here on earth (Rubingh 2002:48). This message of hope will have to play a major role in a Theology of HIV/AIDS if we want it to be relevant for those most in need of the church's involvement in this pandemic.

As we reflect upon what we have heard and start our own formulation on a Theology of HIV/AIDS, let us be humble enough to admit that we do not have all the answers and the answers which we might find during these sessions may not be practical in all countries of the world and among all the people of the world (Müller 2004:2; World Council of Churches 2001:2). Yet, our strength lies in admitting our inability to produce a final answer, and by saying to each other that we need each other as we, as ambassadors of Christ, seek to do something which will bring hope to individuals, families, communities and entire countries facing inevitable death.

During the AIDS conference in Nairobi, the following story was told (World Council of Churches 2001:3):

"When my cousin was dying of AIDS, he found it easy to tell his family and friends about the disease. In his final days we gathered the family together to say goodbye, and discussed with Mathunya the plans for his funeral. We asked him what he wanted to happen at the service, and he said, 'I want you to tell them the truth that I died of AIDS'. So we planned a service that could celebrate his life and educate those who came to the funeral, especially the young people".

At his funeral, my grandmother walked to the front of the church and laid her hand on her grandson's coffin, and said, 'My grandson no longer has to suffer with AIDS.' Then, with her hand still on his coffin, she turned to the pulpit and said to the preacher who was about to preach to the people gathered in the church, 'Now... talk to them freely about this disease.'

\section{SOME SOCIAL CIRCUMSTANCES CONDUCIVE TO THE SPREADING OF HIV/AIDS}

\subsection{World's biggest killer}

A few days before the previous general assembly of the REC took place in Indonesia, a speech was made in Durban, in the province of Kwazulu Natal during the $13^{\text {th }}$ International AIDS Conference. The 
speaker was Thabo Mbeki, the president of South Africa, and what he said during the opening of this conference echoed around the world. In South Africa he was heavily criticised for what he had said. But criticism was not restricted to South Africa alone. Some of the largest international news channels also shared the criticism against the opening speech of the $13^{\text {th }}$ International AIDS Conference (BBC 2000; CNN 2000; Johns Hopkins AIDS Service 2000).

The question is: What did President Mbeki say which angered the world to such an extent that the Boston Globe later even described him as a modern day Pontius Pilate who "practices the art of deceit and denial where AIDS is the issue" (O'Malley 2004)? Basically he was accused of two things, the first one being that he did not believe that AIDS was caused by the HI virus. Secondly, in his speech he had made the remark that HIV/AIDS was not our greatest problem. Poverty was an even larger problem than HIV/AIDS. He quoted from an executive report of the World Health Organization (1995): “The world's biggest killer and the greatest cause of ill-health and suffering across the globe is listed almost at the end of the International Classification of Diseases. It is given the code Z59.5 - extreme poverty", a condition defined by The World Bank as having to live on less than US \$1 per day (Soubbotina 2004:33-34). According to their calculations, by the turn of the century nearly half of the world's population had to live on \$2 per day and more than a fifth of the population had to live on $\$ 1$ or less per day.

It is not my intention to either accuse or defend President Mbeki, although when reading through the script of his opening speech, I could find no reason to believe that he rejects the link between HIV and AIDS. But I have a much greater interest in the second accusation made against him, concerning the link between poverty and HIV/AIDS, as, in my experience, this is indeed true not implying of course that HIV/AIDS is caused by poverty. But there seems to be a link between poverty and HIV/AIDS which cannot be ignored - least of all by the church of Jesus Christ!

During the past few years, an increasing number of people, including some prominent theologians, have recognised the 
connection between poverty and HIV/AIDS ${ }^{3}$. This connection however may not be obvious. On the contrary, the cries that came after President Mbeki's speech argued that HIV/AIDS first occurred among American gay men "as affluent as the rest of US society in the 1980s, when the virus raced through their ranks" (Globe editorial, quoted in Partners In Health s.a.). However, Partners in Health responded by saying that, rather than proving that there was no connection between HIV/AIDS and poverty, quite the opposite was true. The wealthy, gay American men had been able to restrict the spreading of HIV/AIDS to a great extent: "Wealth has determined who gets the necessary resources to stop the disease."

Shortly before he died in an air crash, Dr Jonathan Mann, the first director of the World Health Organization's Global Program on AIDS, wrote: "AIDS is taking advantage of the opportunities society offers it” (Global Citizens Circle 2001). And poverty seems to be creating numerous opportunities which expedite the spreading of the HI virus. Mann based his viewpoint on research which he had done in Zaire from 1984 to 1986 and remarked that HIV/AIDS seemed to flourish in and reinforce conditions of poverty, oppression, urban migration and social violence (Hawa 2001).

Poverty seems to increase and affect the occurrence of this killer disease in two distinct ways, firstly by creating circumstances where more people are getting infected and, secondly, by delaying the process of being treated for the symptoms of this disease.

\subsection{Prostitution}

As people are faced with poverty, there seems to be one universal method of alleviating this problem, whether you are living in Africa, in Asia, in Eastern Europe or, for that matter, in any country in the world. If you have nothing else to sell with which to earn an income, then you sell yourself. As Gillian Patterson says: "The world over, and throughout history, if women have no other way of feeding themselves and their families, they turn to prostitution” (1995:31). Looking at the present situation, the truth of this remark becomes evident. Jonathan Mann, while busy with research in the Philippines, discovered a large number of sex workers, both male and female - in

3 Among others, the following serve as examples: Ackermann (2004b); Brown \& Hendriks (2004a); Pienaar (2003); Clifford (2004:7); Brown (2004). Refer also to my own article in REC Focus (2004). 
a country where prostitution was strictly forbidden - who had chosen prostitution as a last resort to earn some money (Monzon s.a:3). Some of the young men were students earning money in order to afford to go to university, while most of the female workers were helping to support their families. "Most women do not freely choose to be commercial sex workers. Some are forced into prostitution. For others..., it is a choice they make to survive and save their children from starvation” (Brandt 2003:31).

World Vision (2002:1) recorded the following story:

Srey was unusual, yet typical: she was unusual in that she 'willingly' sold herself into a brothel, as 'willing' as her desperate situation could make her. Srey was also typical: she was one of millions of invisible children, in prostitution not for her own ends, but out of family loyalty.

Aged only 13, Srey knew that she was the only hope her sick mother had of accessing health care in Cambodia. She worked as a prostitute until at the age of 15 she was thrown out onto the streets to beg, her body thin and her face drawn, both the result of HIV. World Vision picked Srey up from the streets, and in the remaining ten months of her short life, worked with her to try to recover her sense of self worth. Srey was just one of the nearly 300 sexually exploited children with whom World Vision works in Phnom Penh, almost 20\% of whom are HIV positive. She was typical of other children trapped in prostitution in that she wanted a better life for herself.

UNICEF (2003:28) found the same situation in Zambia. The average age of children engaged in prostitution in that country is fifteen. When doing their research, they found that $47 \%$ of these prostitutes were double orphans and $24 \%$ were single orphans. On average the children slept with three to four clients per day, and the main reason that they gave for doing this was the constant need for money to support themselves, their parents or their children. Whether one goes to India, to Thailand, to the Congo or South Africa, everywhere the same story is told about women caught up in prostitution in an attempt to earn money.

Not all types of prostitution however are done in a formal way. Research done in Durban in South Africa showed that among a large group of young people of all races, it is considered customary that sexual favours may be given in exchange for gifts - gifts ranging 
from things such as chocolate and clothing to more expensive gifts such as vacations. Gifts are also often given to the parents of a girl, making such a person emotionally more vulnerable to the sexual advances of the man. In their study on this topic, Kaufman \& Stavrou conclude (2002:22): "Clearly those adolescents who are economically disadvantaged are at greater risk of trading sexual favors - often unprotected ones - for money or other financial rewards."

\subsection{Migrant labour}

Not all people choose the road of prostitution to earn money. In Southern Africa, others, usually the men, when finding it impossible to be employed in the vicinity of their homes, leave their families and travel to Egoli, the city of gold, more commonly known as Johannesburg. These people are part of the migrant labour force people who work away from their homes, usually living in hostels supplied by the mine or company they work for. They receive good salaries which enable them to take good care of their families, thereby solving the immediate need for money, but migrant labour also has its dangers. Family life becomes virtually non-existent, as it may be weeks or even months before the family will be united again for a day or two after which the man leaves home again to return to his work. Within these unnatural living conditions, the possibility of adultery becomes a much greater reality (Van Wyngaard 2004:9293). Egerö, Hammarskjöld \& Munck (s.a:8) quoted Mark Lurie of the South African Medical Research Council:

If you want to spread a sexually transmitted disease, you'd take thousands of young men away from their families, isolate them in single-sex hostels, and give them easy access to alcohol and commercial sex. Then, to spread the disease around the country, you'd send them home every once in a while to their wives and girlfriends. And that's basically the system we have with the mines.

In the countries most affected by HIV/AIDS the story is heard over and over again of faithful wives waiting at home for their husbands to return, only to find out, when it is too late, that their husbands are HIV-positive. UNAIDS (2004:10) made the shocking discovery that in some countries the HIV-infection levels were $10 \%$ higher for married than for sexually active unmarried girls. In rural Uganda, among HIV-infected women aged 15-19 years, 88\% of the girls 
were married. The reason for this is that young girls often marry older men who had had a variety of sexual partners before.

\subsection{Mother to child transmission}

A third way in which the HI virus is transmitted and which can also be linked to the problem of poverty, is direct transmission from mother to child. By the end of 2004, around $8 \%$ of all people infected with the HI virus were children of whom most had been infected by their mothers (UNAIDS 2004:14). This could happen during pregnancy, during the birth process or through breastfeeding. Many of these infections could have been avoided if the mother had been tested and informed in advance that antiretrovirals, taken shortly before birth, could have prevented her child from becoming infected. However, in poor countries, many children are born at home, usually with nothing more than a caring family member or friend assisting the mother and child. It is estimated that between 60 and $80 \%$ of children who are HIV-positive are infected before and during birth (SAFAIDS 2000:10; UNAIDS 1998:10). The rest will be infected through breastfeeding.

Although it is universally recognised that breastfeeding is the most beneficial for babies, alternatives have to be found in the case where a mother is HIV-positive. Many varieties of options are available. But unfortunately these options always come at a price. And in the end, for the people from poverty stricken areas, there really is no option, other than to breastfeed. It is usually recommended by health officials that a mother who is HIV-positive should breastfeed exclusively for between three and six months, this meaning that nothing else, including water, should be given to the baby. When the baby is ready to start eating other food, then breastfeeding should be stopped abruptly and from that point the baby may no longer be fed by the mother (Van Wyngaard 2004:9394).

In sub-Saharan Africa, and probably in many other countries as well, breastfeeding is as normal as having a cup of tea. Most children are breastfed for more than a year. This not only has to do with the culture, but it is also an economical decision - the mother's milk is free. In a home where people hardly have enough to feed themselves, it is difficult to imagine that an option to wean a child at the age of three months will be taken. As Brandt (2003:31) says: "In truth, infant formula is not an option for most African women due to 
unsafe water, unavailability of infant formula or poverty. Under these conditions World Vision and the World Health Organisation (WHO) advise women to breastfeed, knowing that there is a possibility that some children will become infected with HIV"

In the process, more and more children are becoming infected with the deadly virus.

\subsection{Antiretrovirals}

As we all know, there is no cure for HIV/AIDS. Antiretrovirals, (ARVs) however, can extend a person's life by many years and can increase the quality of life to such an extent that a person with HIV/AIDS can lead a relatively normal life for many years. Around the turn of the century, Harvard University estimated that the annual cost of treating someone with HIV/AIDS would be about $\$ 1,100$ (Connelly 2002:3). This price includes HIV tests, drugs, labour for directly observed therapy, diagnostic tests, and clinical visits. Many other organisations, including large mining groups and medical aid schemes, have also done research on this topic. Most of them have estimated an even higher cost per person for the treatment of HIV/AIDS (Connelly 2002:6-10). But then one thinks about the words of President Mbeki during the opening of the Durban AIDS Conference, when he said: “...today the money that some developing countries have to spend per person on health care over an entire year is just US \$4 - less than the amount of small change carried in the pockets and purses of many people in the developed countries" (Mbeki 2000).

One of the reasons why most of the developing countries are so poor, is the extreme debt burdens which these countries have. Some countries spend $40 \%$ of their national budget on debt servicing (Hawa 2001:3), while Felix Mutua writes: "Whereas Africa has only a paltry $5 \%$ of the developing world's income, it is saddled with two-thirds of the debt burden - over $\$ 300$ billion. Thus, the average African country spends three times more of its scarce resources on repaying debt than it does on providing basic services” (2004:2). Paula Clifford (2004:1) regards this as one of the primary reasons why HIV/AIDS seems to be totally out of control in most developing countries and she sees this as a challenge which the church will have to speak out against, in order for things to change:

...the church must make its voice heard in order to change the structures that are assisting the spread of HIV. Most crucially, 
this means working to alleviate poverty by advocating for change in unjust trade practices and the removal of the burden of unpayable international debt. A theology of hope and love must be accompanied by practical care, which not only aims to improve people's quality of life within their community, but also demands action in the wider world.

As poverty is making the treatment of HIV/AIDS extremely difficult on a larger scale in most developing countries, the same can be said of the treatment of HIV/AIDS on an individual level. ARVs are out of reach of the extremely poor, even though the price of generic drugs has been drastically reduced. Globally, by 2004, still only about $12 \%$ of all people infected with HIV/AIDS had been receiving ARVs (Berry \& Kanabus 2005). Even at the comparatively low price of $\$ 140$ per year, the extremely poor cannot afford to pay for their medication. Their only resort therefore is to apply for help at hospitals and clinics authorised to test patients and to supply the necessary drugs once it has been confirmed that the individual does indeed have HIV/AIDS and that the viral count in the blood is low enough to justify treatment. But even this is not as easy as it sounds. During a personal conversation with a social worker working in a hospital in Manzini, Swaziland, I asked her whether the distribution of ARVs is successful in Swaziland. The answer she gave me was that ARVs are being distributed successfully at the hospital, but due to the cost of travelling with public transport from the rural areas to Manzini, many people with HIV/AIDS are receiving ARVs for one or two months, after which the travelling costs become too high and treatment is terminated or only taken intermittently thereafter.

\subsection{Abuse of women and the spreading of HIV/AIDS}

I have discussed the role that poverty is playing in the spreading of HIV/AIDS in some detail. However, poverty is not the only social problem which promotes the spreading of the disease. The church will also need to take note of the role of woman in families and society if it wants to formulate a relevant Theology of HIV/AIDS. It is not surprising that more women than men are suffering from HIV/AIDS. According to UNAIDS (2004:21) approximately thirteen women are infected with the virus for every ten men infected. Obviously, physically a woman is more susceptible to the virus. But this is not the only reason. In their report UNAIDS says: 
Sexual abuse and violence - much, but not all of it directed against females - are serious problems that transcend economic, social, ethnic and geographical lines. Adolescents, children and young women and girls in particular experience increased abuse in the form of domestic violence, rape and sexual assault, and sexual exploitation (2004:23).

This abuse against women starts at a very young age. In Swaziland, as in some other sub-Saharan countries, there is a myth that sex with a virgin will cure a man of HIV/AIDS. Consequently, girls of a very young age are increasingly being raped and thus infected with HIV (Neilson 2004:1; Brandt 2003:29). As these girls grow older, the abuse is continued, often within permanent relationships. Research done in countries such as Rwanda, Tanzania and South Africa have shown that there is a strong link between intimate partner violence and an increased likelihood of HIV infection in women (UNAIDS 2004:12). Further research has shown that women who are sexually abused are more likely to engage in unprotected sex and to have multiple partners later in life (SAFAIDS 2000:10). Social norms often make it extremely difficult for women to discuss sexual issues with their partners. In many households negotiating condom use is out of the question. Any attempt to do this may lead to violence and forced sex with the woman (UNAIDS 2000:50), increasing the possibility that the women may become infected through raptures in the vaginal tissue through, what is known as domestic rape. Brandt (2003:30) recorded the following event:

Even a woman like Mai Esther, with grown-up children and authority as a community leader who considered herself to be a moral Christian woman, could not have stopped her husband from sleeping with her even if she suspected that he might have HIV. Indeed, refusing him sex or asking him to use condoms might have suggested that she had engaged in extramarital sexual activity in his absence. One day, Mai Esther did have the courage to ask him to use a condom during one of his visits. He reacted with anger and beat her, before abandoning her in favour of the second wife.

Research done in Malawi among woman illustrated the hopeless situation within which they find themselves: One married woman, named Sela, shared the following story about her husband: 
If I refuse to accept his advances, he can get physical and several times he has hurt me. A number of times he has hit me when I have refused to have sex with him because I know that he was with someone else. It feels as though I am being raped. It is very difficult to protect myself in this situation and I fear for myself.

Other women verbalized their agreement with her concerns, 'What can you do if he is going to beat you and demand that you have sex with him? Even if there is AIDS these days you just have to accept your fate and continue to sleep with him because he beats you. He says I am his wife and can do this with me whenever it pleases him' (Brown, 2004:91).

Towards the end of his opening speech at the Durban AIDS Conference, President Mbeki said: "As I listened and heard the story about our own country, it seemed to me that we could not blame everything on a single virus” (Mbeki 2000:5).

Indeed, realising the devastating effects of poverty and the abuse of females within homes and society, one has to realise that, in order to rid the world of HIV/AIDS, much more needs to be done than simply to find a cure or a vaccine for the virus. We will have to ask the question: How does God feel about poverty, injustice in the workplace, unrealistic expectations from employees, abuse of women both in and outside marriage and many other social problems, none of which cause HIV/AIDS, but many of which are conducive to the spreading of HIV/AIDS? In a Theology of HIV/AIDS, the church will then have to formulate this in a clear way for all to see what the church's view is on these matters. This calls for a prophetic voice to be heard, speaking out against all forms of social injustice.

\section{SOCIAL CONSEQUENCES OF HIV/AIDS}

\subsection{Stigmatisation and discrimination}

Some of the most often quoted words regarding HIV/AIDS are the words of Gideon Byamugisha, an Anglican priest from Uganda, who himself is HIV positive. He said (quoted, amongst many others, in World Council of Churches 2001:1):

It is now common knowledge that in HIV/AIDS, it is not the condition itself that hurts most (because many other diseases and conditions lead to serious suffering and death), but the stigma and the possibility of rejection and discrimination, misunder- 
standing and loss of trust that HIV positive people have to deal with.

Many people who have done research on HIV/AIDS consider stigmatisation as the number one reason why HIV/AIDS cannot be curbed.

What is stigma? During a theological workshop held in Windhoek, Namibia in December 2003, which focussed specifically on HIV- and AIDS-related stigma, the following was said: "Stigma is difficult to define. Generally, though, it implies the branding or labelling of a person or a group of persons as being unworthy of inclusion in human community, resulting in discrimination and ostracization” (UNAIDS 2005:11).

The problem of stigmatisation could probably best be described by way of a story:

At the World AIDS Day celebration in the Roman Catholic Cathedral in Bujumbura in 1995, the priest said, in the course of his sermon, "We must have compassion for people with AIDS because they have sinned and because they are suffering for it now”. At that point something propelled Jeanne Gapiya to rise from her pew and walk up to the front of the church. "I have HIV", she declared, "and I am a faithful wife. Who are you to say that I have sinned, or that you have not? We are all sinners, which is just as well, because it is for us that Jesus came" (Brown \& Hendriks 2004b:27).

Stigmatisation has many social consequences, most of which make it extremely difficult to address the pandemic effectively. One of the direct results of the stigma linked to HIV/AIDS is denial that the problem exists (UNAIDS s.a:1). While the problem is being denied, it is impossible to find a solution. Denial takes place on at least three levels: denial by those not affected by HIV/AIDS - in other words, the "healthy" people who feel that this has nothing to do with them; denial by entire countries affected by HIV/AIDS who fear the consequences if the facts should become known, and denial by individuals affected by HIV/AIDS (Van Wyngaard 2004:90-91). Stigma feeds on denial, according to UNAIDS (2005:16) - but actually the one feeds the other: as long as people with HIV/AIDS are stigmatised, the problem will be denied and as long as the problem is denied, those with HIV/AIDS will be stigmatised. The church has probably been as guilty of denying the reality of 
HIV/AIDS as any other body. During the African Religious Leaders Assembly on Children and HIV/AIDS held in Nairobi in 2002, the following important words were included in the final delaration of the conference: "Our messages have not always been consistent and our voices have not always been heard. We have been reluctant to speak openly about HIV/AIDS. Too often our own ignorance, fear and denial have held us back as teachers about HIV/AIDS in our communities" (WCRP 2002).

Obviously it is not only the church that is at fault. However, in a Theology of HIV/AIDS it may be appropriate for the church to humbly set the example in admitting our own failure to speak prophetically about HIV/AIDS before the pandemic escalated to the magnitude it presently has.

Directly linked to the problem of stigmatisation is discrimination. These two terms seem to be inseparable from each other (Clifford 2004:8). So serious is the problem of stigmatisation and discrimination, that it has even been described as a second epidemic, next to HIV/AIDS (Dube 2003:vii). Stigma and discrimination supplies the fuel for HIV/AIDS, as it hampers prevention and care efforts through silence and denial about HIV/AIDS, as well as marginalising those who are affected by HIV/AIDS (UNAIDS s.a:1). This fear of stigmatisation and discrimination leads to an endless circle of denial and silence: "Fear of stigma makes people afraid to reveal their positive status by changing their behaviour. This means that men and women continue to have unprotected sex, intravenous drug users continue to share needles, and HIV spreads faster than ever" (Clifford 2004:9). In a Theology of HIV/AIDS stigmatisation and discrimination will have to be exposed for what it really is, which is: "sinful, in that they deprive HIV-positive people of the freedom to live openly, seek treatment and enjoy a normal life" (Clifford 2004:14).

A further result of stigmatisation is the creation of a false sense of security for those not infected with HIV/AIDS. When HIV was first discovered in the early 1980s, it was primarily found among homosexuals. The rest of the world gave a sigh of relief knowing that they were safe from the "gay plague" and continued with their lifestyles, wrongly believing that they were protected from infection - with devastating results. 


\subsection{Plight of widows and orphans}

If men are suffering under the consequences of HIV/AIDS, then women are suffering even more. Not only are the majority of people infected with the HI virus female, but when it comes to caring for these people, virtually the full load falls upon the woman's shoulders. Sunette Pienaar $(2003: 20 ; 104)$ tried to express the frustration of the female caregivers in this situation. She tells the story of a young lady by the name of Noluthando, who had to care for her dying sister, Dina. As the story unfolds, we are told of the childhood dream of the young Noluthando - she wanted to become an engineer. But this dream was shattered when it became known that her sister had HIV/AIDS and Noluthando, with the help of her mother, had to look after Dina, spending all her time cleaning, washing, cooking and caring for her sister and her own daughter. HIV/AIDS and the burden which fell on her shoulders to care for her sister, had robbed her of her hope to study and to become an engineer. This is the actual story of one individual named Noluthando, but it is also the story of hundreds of thousands of other women whose names we do not know and whose ambitions for a better life had to be exchanged to fulfill the expectation that they would become caregivers for their sick family members and for the orphans left behind after the parents had died.

The AIDS-widows also face a bleak future. The majority of these widows are fairly young, seldom with children old enough to care for her, as is the custom in many cultures. In many cases the land on which the family resided while the husband was still alive, is reclaimed by the husband's family, leaving the woman without a home.

The problem of AIDS-orphans is even greater than the problem of AIDS-widows. By the turn of the century around 7 million children under the age of fifteen had lost their mother or both of their parents. It is expected that by 2010 this number will have doubled (Egerö, Hammarskjöld \& Munck s.a:31). In most cultures the orphans are cared for by the extended family - often the grandparents. However, as the grandparents witness their children dying of HIV/AIDS, one after the other, it becomes impossible for them to care for the increasing number of orphans, resulting in homes consisting entirely of underage children, children ending up in the street or children being used as domestic workers (SAFAIDS 2000:13). Many of these children will be raped or will turn to 
prostitution to earn money, increasing the probability of their also becoming victims of HIV/AIDS.

This reminds one of the plight of the widows and orphans so often described in the Bible. In a Theology of HIV/AIDS it will be necessary for the church to side with those who cannot fend for themselves any longer.

\subsection{Funeral costs}

As the occurrence of HIV/AIDS continues to escalate in the poorest countries of the world, this leads to even greater poverty, becoming a vicious circle from which there is little chance to escape. Where medication such as antiretrovirals cannot be afforded, the inevitable death of the patient is accepted. However, once the patient has died, the costs involved continue to increase. Archbishop Njongonkulu Ndungane of South Africa (2004:199) explains this in the following way:

HIV/AIDS deaths are also a major cause of chronic poverty. There is a classic cycle in which a head of household contracting AIDS leads to reduced earnings due to ill-health, higher expenses on medical bills and traditional cures, asset depletion (sale of assets, withdrawal of children from school), and further drops in income. When the head of the household dies there are funeral expenses and the remaining household members are left in an assetless or indebted state of persistent poverty.

Recent research done in South Africa found that households with HIV/AIDS related deaths spent an average of one third of their annual income on funerals (UNICEF 2003:15). In Africa, funerals are expensive. Not only the friends and relatives of the deceased turn up for the funeral. Virtually the entire community where the deceased lived will attend the funeral. These people have to be fed. On the day of the funeral all those attending have to receive a proper meal, consisting of meat and vegetables at the very least. Sunette Pienaar (2003:121-122) recorded the following actual expenses during the funeral of Dina: Her father, who did not have a permanent occupation, had to pay for the renting of a tent, chairs, a sound system, toilets, the undertaker, the coffin and the grave. A family member offered to pay for three buses to transport people from the home to the graveyard. A cow was bought which had to be transported about one hundred kilometres to the homestead where 
the funeral took place. In all, the costs for the funeral added up to around R13000 (approximately US\$2000).

If one recalls that the World Bank estimates that nearly half of the world's population live on \$2 per day and more than a fifth of the population have to live on $\$ 1$ or less per day, then it becomes clear why HIV/AIDS is considered to be instrumental in the spiralling problem of poverty. It is not just a normal disease. It is a disease that destroys one's dignity, that destroys entire families and that destroys the economy.

\section{CONCLUSION}

Will we be able to make a difference? To answer this, I would like to repeat the words used in Nairobi in 2001:

The churches have strengths, they have credibility, and they are grounded in communities. This offers them the opportunity to make a real difference in combating HIV/AIDS. To respond to this challenge, the churches must be transformed in the face of the HIV/AIDS crisis, in order that they may become a force for transformation - bringing healing, hope, and accompaniment to all affected by HIV/AIDS (World Council of Churches 2001:3).

As my last word, I would like to repeat the story told at the same conference in Nairobi (2001:3):

When my cousin was dying of AIDS, he found it easy to tell his family and friends about the disease. In his final days we gathered the family together to say goodbye, and discussed with Mathunya the plans for his funeral. We asked him what he wanted to happen at the service, and he said, 'I want you to tell them the truth that I died of AIDS'. So we planned a service that could celebrate his life and educate those who came to the funeral, especially the young people.

At his funeral, my grandmother walked to the front of the church and laid her hand on her grandson's coffin, and said, 'My grandson no longer has to suffer with AIDS.' Then, with her hand still on his coffin, she turned to the pulpit and said to the preacher who was about to preach to the people gathered in the church, 'Now... talk to them freely about this disease'.

As we formulate a Theology of HIV/AIDS, we are learning to face the reality with which the world is faced today. As we formulate a Theology of HIV/AIDS, we are learning to speak freely about this 
disease. We may no longer speak about them and us. It is God's children, our brothers and sisters, who are dying of HIV/AIDS. If one member suffers, all suffer together (1 Corinthians 12:26). It is time to speak the truth. It is time to act only out of love. It is time to overcome fatigue and denial. And it is time to live in hope of a better future.

\section{Consulted literature}

Ackermann, D M 2004a. Seeing HIV and AIDS as a gendered pandemic. Ned Geref Teologiese Tydskrif 45:2 (Supplementum), 214-220.

-, 2004b. Tamar's cry: Re-reading an ancient text in the midst of a contemporary pandemic. Ned Geref Teologiese Tydskrif 45:2 (Supplementum), 300-316.

Algemene Kommissie Vir die Diens Van Barmhartigheid 2002. Standpunt MIV en VIGS. Handelinge van die Elfde Algemene Sinode van die Nederduitse Gereformeede Kerk, 534-535.

BBC 2000. Pressure on Mbeki over Aids. <http:/ews.bbc.co.uk/1/hi/health/ 833306.stm> (Accessed 17 June 2005).

Berry, S \& Kanabus, A 2005. Providing Drug Treatment for Millions. $<$ http://www.avert.org/ drug-treatment.htm> (Accessed 24 June 2005).

Boston Globe 2004. A South African 'genocide' in AIDS policies. <http:// www.boston.comews/globe/editorial_opinion/oped/articles/2004/04/13/a_so uth_african_genocide_in_aids_policies/> (Accessed 17 June 2005).

Brandt, D 2003. Violence Against Women: From Silence to Empowerment. California: World Vision.

Brown, J \& Hendriks, H J 2004a. Understanding HIV/AIDS through the dark lens of poverty. Ned Geref Teologiese Tydskrif 45:2 (Supplementum), 403415 2004b.

-, The AIDS Fulcrum: The Church In Africa Seesawing Between Alienation, Estrangement, Prejudice And Love. Practical Theology in SA 19:2, 19-36.

Brown, J L 2004. HIV/AIDS Alienation: Between Prejudice and Acceptance. Unpublished DTh Thesis: University of Stellenbosch.

Clifford, P 2004. Theology and the HIV/AIDS epidemic. s.l.: Christian Aid.

CNN 2000. Hundreds walk out on Mbeki at AIDS conference. <http:// archives.cnn.com/2000/HEALTH/AIDS/07/10/aids.economics/> (Accessed 17 June 2005).

Connelly, P 2002. The Cost of Treating HIV/AIDS with ARVs in South Africa: Who Knows? Who Cares? <http://www.iaen.org/files.cgi/6929_connelly2. $p d f>$ (Accessed 21 June 2005). 
Diensgroep Diensgetuienis 2004. MIV en VIGS. Agenda vir die Twaalfde Sitting van die Algemene Sinode van die Nederduitse Gereformeerde Kerk, 24-32

Douma, J 1987. AIDS - Meer dan een ziekte. Kampen: Van den Berg.

Dube, M W 2003. Towards Multi-Sectoral Teaching in a Time of HIV/AIDS, in Dube, M W (ed): HIV/AIDS And The Curriculum: Methods of Integrating HIV/AIDS In Theological Programmes, Geneva: WCC, vi-xii.

Egerö, B, Hammarskjöld, M \& Munck, L s.a.. AIDS: The Challenge of this Century: Prevention, care and impact mitigation. Stockholm: Sida.

Global Citizens Circle 2001. Global AIDS and The Human Right To Health. <http://www.global-citizenscircle.org/programs/2002/jan02.html> (Accessed 18 June 2005).

Haspel, M 2004. Christian Sexual Ethics in a Time of HIV/AIDS - A Challenge for Public Theology. Verbum et Ecclesia 25:2, 480-501.

Hawa, R S 2001. Africa: Poverty and the AIDS virus. <http://www. twnside. org.sg/title /poverty.htm> (Accessed 30 May 2005).

Johns Hopkins AIDS Service 2000. The World AIDS Conference in Durban, South Africa - Science, Politics, and Health. <http://www.hopkins-aids.edu/ publications/report/sept00_1.html> (Accessed 17 June 2005).

Kaufman, C E \& Stavrou, S E 2002. "Bus Fare, Please”: The Economics of Sex and Gifts Among Adolescents in Urban South Africa. <http://www. synergyaids. com/documents/SouthAfrica_economicsOfSex. pdf $>$ (Accessed 29 May 2005).

Louw, D J 1988. VIGS: Die radikale siekte met 'n radikale uitdaging aan die pastorale bediening. Ned Geref Teologiese Tydskrif 29:1, 66-79.

Maluleke, T S s.a.. Towards an HIV/AIDS-Sensitive Curriculum. <http://www. wcc-coe.org/wcc/what/mission/dube-7.html> (Accessed 6 June 2005).

Masenya, M 2001. Between unjust suffering and the "silent" God: Job and HIV/AIDS sufferers in South Africa. Missionalia 29:2, 186-199

Mbeki, T 2000. Speech of the President of South Africa, Thabo Mbeki, at the Opening Session of the 13th International AIDS Conference, Durban, 9 July 2000. <http://www.info.gov.za/ speeches /2000/000714451p1001.htm> (Accessed 30 May 2005).

McDonagh, E 1994. Theology in a time of AIDS. s.l.: CAFOD

Monzon, O, T s.a.. Jonathan Mann: 1947-1998. <http://www.ibe.unesco.org/ International/Publications/Thinkers/ThinkersPdf/manne.pdf> (Accessed 18 June 2005).

Müller, J 2004. HIV/AIDS, Narrative Practical Theology, And Postfoundationalism. The Emergence of A New Story. Pretoria: University of Pretoria. 
Mutua, F 2004. Aids Is Essentially A Poverty-linked Pandemic. <http:// www.trocaire.orgewsandinformation/mwangaza/Mwangaza\%20(AIDS).pdf $>$ (Accessed 20 June 2005).

Ndungane, N 2004. Poverty and the church. Ned Geref Teologiese Tydskrif 45:2 (Supplementum), 197-200.

Neilson, K 2004. Swaziland: Land of Contrast. Sussex: World Hope (Canada).

O’Malley, P 2004. A South African 'genocide' in AIDS policies. <http://www. boston.comews/globe/editorial_opinion/oped/articles/2004/04/13/a_south_af rican_genocide_in_aids_policies/> (Accessed 18 June 2005).

Partners In Health s.a.. Misunderstanding Mbeki. <http://www.zmag.org/misunderstanding_mbeki.htm> (Accessed 30 May 2005).

Patterson, G 1995. Love in a Time of AIDS: Women, Health and the Challenge of HIV. Geneva: WCC Publications.

Pienaar, S 2003. The Untold Stories of Women in Historically Disadvantaged Communities, Infected and/or Affected by HIV/AIDS, about Care and/or the Lack of Care. Unpublished PhD Thesis: University of Pretoria.

Pocock, J W 2003. Humanity in Crisis: HIV/AIDS and its Impact on the Church and Community in South Africa. Unpublished Masters Dissertation: University of Pretoria.

Race And History 2001. AIDS: Misunderstanding Mbeki. <http://www. raceand-history.com/self-news/viewnews.cgi?newsid1001760898,77054,> (Accessed 17 June 2005).

Reid, G 1987. Beyond AIDS: The real crisis... and the only hope. Sussex: Kingsway Publications.

Rubingh, E 2002. Theological and Ethical Reflections on HIV/AIDS in Africa. REC Focus 2:1, 44-64.

Saayman, W \& Kriel, J 1991. Towards a Christian response to AIDS. Missionalia 19:2 (August), 154-167 1992. AIDS: The Leprosy of our time? Towards a Christian response to AIDS in Southern and Central Africa. Johannesburg: Orion.

SAFAIDS 2000. HIV and AIDS Surveillance: Fact Sheet 1. Harare: SAFAIDS.

Soubbotina, T P 2004. Beyond Economic Growth: An Introduction to Sustainable Development Washongton DC: World Bank.

UNAIDS 1998. Report on the global HIV/AIDS epidemic: June 1998. Geneva.

UNAIDS 2000. Report on the global HIV/AIDS epidemic - June 2000. Geneva.

UNAIDS 2004. AIDS Epidemic Update: December 2004. Geneva.

UNAIDS 2005. A Report of a Theological Workshop Focusing on HIV-and AIDS-related Stigma. Geneva. 
UNAIDS, s.a.. Understanding HIV/AIDS related stigma and discrimination. Geneva: UNAIDS.

UNICEF 2003. Africa's Orphaned Generations. New York: UNICEF.

Van Der Walt, B J 2004. Is Vigs die oordeel van God oor ons ongehoorsaamheid? Woord en Daad, Potchefstroom.

Van Houten, R L 2002. HIV/AIDS: An Overview. REC Focus 2:1 (March), 243.

-, 2003. HIV/AIDS: An Update, 2002. REC Focus 3:1 (March), 56-67.

-, 2004. HIV/AIDS: An Update, 2003. REC Focus 4:1 (February), 74-88.

-, 2005. HIV/AIDS: An Update, 2004. REC Focus 5:1 (March), 33-45.

Van Wyk, J H 1990. Vigs en Moraliteit. Instituut vir Reformatoriese Studie 267 (Maart), 1-16.

Van Wyngaard, A 2004. Why are we losing the battle against AIDS? REC Focus 4:1 (February), 89-97.

Vitillo, R J s.a.. Caritas Internationalis Continues Its Commitment to HIV/AIDS - Response of the Church. <http://www.ncan.org/resourcesewsletter/caritas.cfm> (Accessed 5 June 2005).

WCRP 2002. African Religious Leaders Assembly on Children and HIV/AIDS. $<$ http://www.wcrp.org/RforP/Press\%20Releasesews_Nairobi AssemblyDeclaration.html> (Accessed 2 July 2005).

World Council of Churches 2001. Plan of Action: The Ecumenical Response to HIV/AIDS in Africa. Global Consultation on the Ecumenical Response to the Challenge of HIV/AIDS in Africa, 1-10

-, 2004. Facing AIDS : The Challenge, the Churches Response. Geneva: WCC Publications World Health Organization 1995. Executive summary. <http://www.who.int/whr/1995/media_centre/executive_summary1/en/print. html> (Accessed 18 June 2005).

World Vision 2002. 'No child of mine!': Opening the world's eyes to the sexual exploitation of children.

$<$ http://www.child-rights.org/PolicyAdvocacy/pahome 2.5.nsf/0/23A5B878BB98798A88256E46008360CF/\$fileo\%20child\%20of \%20mine.pdf $>$ (Accessed 20 June 2005). 